第74回日本内科学会講演会 (1977年)

\title{
シンポジゥム 細菌感染症の化学療法
}

（1）わが国に护ける細菌感染症

ii ) (招請) 病院感染症の実態とその制御

岩手医科大学医学部細菌学教室

川名 林治

\section{SYMPOSIUM ON THE CHEMOTHERAPY OF BACTERIAL INFECTION}

(1) THE BACTERIAL INFECTION IN JAPAN

ii ) PREVENTION AND CONTROL OF THE HOSPITAL INFECTION

Rinji Kawana, MD

Department of Bacteriology, School of Medicine, Iwate Medical University, Morioka

\section{1. 腥 言}

病院感染 (または院内感染) (hospital infection, nosocomial infection) は古くから知られていた が, 近年医療の高度, 複雑化, ここに化学療法の 普及に伴い，従来は弱毒ないしは常在菌之考え られていた緑膿菌，クレブシェラ，セラチフなど をはじめとするグラム陰性桿菌が, 在来のブドウ 球菌などのグラム陽性球菌などよりる, 主役を演 ずることが明らかとなり，また臨床ウイルス学の 進歩により, 種々のウイルスによる院内感染, さ らに宿主の抵抗力の減弱や菌交代症に上る真菌感 染などが，その起因の微生物として注目されてい る.

感染症は最近, 著しい変貌をとげつつあるが, 病院感染もまた状勢の变化をとげつつある。

従つて, 医療にたずさわるものとして, 病院感 染の問題には特に留意し, 従前とは全く新しい観 点からの配慮と対策とが早急にたてられなければ ならない。

折角, 治療のため入院加療中の患者に感染を起 こすとか, 新生児の感染などは, 医療の面から重 大な問題であり，さらに病院勤務者の感染も時と してみられることで, 医学的には勿論, 病院管理
上にも,さらに医の倫理の面からも，社会的に も, 非常に重要な課題である.

従つて, 病院感染を防止するためには，その発 生要因の分析をおこない，微生物学の基礎にたつ た系統的かつ積極的な制御がなされなければなら ない。

\section{2. 病院感染とは}

病院感染とは, 病院内において, 患者は勿論, 新生児など，さらに病院勤務者などが，何らかの 機序によつて，微生物による感染（内因性に世よ 外因性にせよ）をうけ，発症することをさしてい る。

その中には，病院といら特殊な環境内において 起こる感染症を含んでいる．また入院中などに感 染し，退院後発症したものるこれに含めている.

しかし, 入院前に感染し(市中感染), 入院後に 発症したものは, 病院感染とはよばない。

\section{3. 病院感染の疫学}

病院内に打ける感染は, 微生物, 感染経路扣よ び感受性のある個体との関連に加えて, 病院の環 境, 種々の医療や検査, さらに一般に抵抗力の減 弱した患者と。複雑な関連がある。

病院感染の起こりかたは, 次の二つに大別する 
ことができる。

(1) 外因感染 (exogenous infection)

個体の外からの徽生物の感染で, ヒトからヒト へといらよらな感染で，交叉感染cross infection， または水平感染horizotal infectionといい5:

例之ば，同一病室内での，ブドウ球菌，緑膿 菌, さらに水痘, 麻疮, ムンプスウイルス感染の 如きすのである。

（2）内因感染 (endogenous infection)

患者の抵抗力の減弱や，菌交代症などから，本 来, 常在菌などとして, 保有している微生物によ る自己感染によるもので, 墨性腫㾤, 白血病, あ るいは䁍器移植後などにしばしばみられるむので ある.ささらに進展して, 終末感染 (terminal infection）を起こして死に至ることるある.

ことに, 病院には病める弱れる者の集団として の患者が, 元来, 病原性がないか, または弱毒 の微生物によつて，その抵抗力の減弱をらかがう ようなopportunistic pathogensによるopportunistic infectionが，しばしば起こることは，とくに最近 の医療の面から注目しなければならない。

その他, 病院, 市中を問わず，今回の如き，風 疮の大流行の際には，患者; ことに妊婦検診の 来診者, さらに従事者の風疹罹患に上る垂面感染 (vertical infection) の結果としての先天風疹症候 群児の出生には充分の留意が必要である.

\section{4. 病院感染の発症の因子}

1）微生物の立場から

細菌では,ブドウ球菌が主流をなしたが，最 近は緑膿菌, クレブシェラ, プロテウス, 七ラチ ア, 大腸菌などのグラム陰性桿菌によるものが激 増の傾向にある：ことに多戍耐性のものが多い。

勿論, 腸チフス菌, サルモネラ, 赤痢菌などの 腸内細菌は，給食の面からす大切である。

結核菌は古くから知られているが，無芽胞嫌気 性菌などる注目される。

真菌は，菌交代症や，内因感染の結果としてみ られる場合が多く,カンディダ・アルビカンス, アスペルギールス，クリプトコッカスその他が知
られる。

ウイルスによるものは，細菌のそれよりも広汎 な流行をみることが時としてある．かぜ症候群の ウイルスとして，フデノウイルス，インフルェン ザウイルス，パラインフルエンザウイルス， RSウ イルス，コロナウイルス，ムンプスウイルス，そ の他, また, 発疹性のむのとして, 麻疹ウイル ス, 水痘・帯状疱瘆ウイルス, 風疹ウイルス, 一 ルペスウイルスなど，またエンテロウイルスのよ らに多彩な病像を示するのなど，さらに近年は肝 炎との関係でHBs抗原などが注目されている。

2) 感染経路

直接接触感染, 間接間接として飛沫, 痤芥, 领 食物，創傷，火傷，あるいは単族昆虫媒介による ものがある。

これらは外因感染の場合が多いが，内因感染の 場合は常在菌叢や宿主との関係で考えなければな らない。

病院環境はいかに衙生管理に留意しても，一般 社会やホテルなどの市中に比し, 細菌, 真菌, ウ イルスなどにより污染され，また多数の患者やそ の排泄物によつて常に感染の危険にさらされてい ることを忘れてはならない。

手術その他の処置, 検査に上る感染もありらる ことは周知の通りである。

感染経路は入院患者 $\rightarrow$ 入院患者, 入院患者 $\rightarrow$ 職 員, 職員, 見舞人, 外来患者 $\rightarrow$ 入院患者といら交 叉感染が多いが，内因感染も今後増加するものと 思われる。

3）宿主側から

病院には顕性ないし不顕性の感染症患者が少な からず入院している。また一方では未熟児，新生 児, 高令者とか, 悪性腫瘍, 白血病々の他の血液 病, 肝炎, 肝硬変, 膠原病, 腎炎, ネフローゼ, 糖尿病, 脳血管障害, 春髄炎, 骨䯣腫, 免疫不全 などの患者, また火傷, 外傷, 手術後, 気管切開 等々，感染症に䍜患しやすい状態の患者が多数入 院している.しかもしばしば大部屋の条件で同室 している。 
しかもこれらの種々の基礎疾患を有する患者 は，各種の抗生剤などによる化学療法を長期間に わたり実施されることが少なくなく，また，抗畽 痬剤, 抗白血病剤，ステロイド，免疫抑制剤なと の長期投与などる行なわれているとか，さらにレ ントダン，コバルト，ラジウムなどの放射線療 法，また各種の大手術や，穿刺，カテーテル，ブ ジー等の挿入や留固, 人工透析, 腹膜潅流, 輸血 や，連日の輸液などが実施されている。

新生児の沐浴，未熟児の保育など，特殊な操作 が行なわれている。

臨床の各科, 内科系, 外科系など，それぞれの 特殊性はあるにせよ，これらの状況ではいつ病院 感染が起こるかる知れないといえよう。

\section{5. 二, 三の病院感染の実例}

（1）ブドウ球菌では，大船渡病院での新生児 の病院感染を調查答申した。

1973年より新生児室において，数力月間に21名 の新生児の膿皮症と，これにひきつづいて全身感 染により4名の死亡を出したもので，病原は黄色 ブドウ球菌80/81型で，多郕耐性菌であつた。

ブドウ球菌によるものは，内外にきわめて多く の実例がある。

（2）緑膿菌による病院感染は，目下主役の一 つといえょ5. 発症の大小はとるかく，とこの病 院でも大問題といえる。

多くの病院で, 病棟, 詰所, 病所の手洗いや流 し場などは，きわめて広沉に緑膿菌が分布してい る.また，膿汁，尿，喀痰などの病的材料からの 検出率も逐年的に增加の㑯向がみられる。

本学でも，1974年夏，脳神経外科で交通外傷な どによる脳神経系の障害患者の病室において本菌 による病院感染が起こつた。病巣部の膿汁のみな らず，褯創部，気管切開部，尿などから長期間に わたつて緑膿菌が検出された。幸い努力の甲斐が あり制圧できた。

緑膿菌感染は, 重症患者や術後患者の多い, 外 科系や，口控外科，泌尿器科などではしばしばみ られるが, 感染予防と, 早期の防疫が重要である
と考える。

緑膿菌は, 健康者でる常在菌的に見出されるこ とが少なくないので，細心の注意が肝要であると 考光る.

（3）サルモネラ, 赤琍菌その他

病院給食を介しての, 病院内での, サルモネラ による食中毒中，細菌性赤脷なども，時として， 大流行として爆発的に発生することがある．給食 による流行を25年ほど前に経験したことがある.

その後，食養に批ける衛生管理，ことにネズミ の駆除，食養関倸者や出入業者などの定期検便の 徹底，衙生教育などにより，全く事故発生はなく なつた。

最近，サルモネラによる受の産院に括ける新生 児と，その家族などの感染の大きな事件は，サル モネラによる環境の著しい污染からる，今後巣重 な注意がのぞまれる問題といえる。

(4) ウイルス

やく25年ほど前，本学附属病院に拈いても，ア デノウイルスによる眼科病室内の流行性角結膜 炎また，時折の散発などをみた。

また，第一内科の 9 階病棟内でのコロナウイル スによる流行を経験報告した：この際は，大部屋 での感染率が著明で，個室では感染しないるのが あつた。また，肝，消化器系の疾患などの基礎疾 患を有する患者が多かつたためか，疾患の経過が 長いのが注目された。コロナウイルスにかんして は世界で，その報告が唯一のむのである．

一般に，かぜ症候群のウイルスによるるのは， 不可抗力の場合が少なくないが，インフルエンザ のよらにワクチンのあるものは，予めの予防接種 が望まれる。

ことに，乳幼児では，RSウイルスゃパライン フルエンザウイルスによる感染は，下気道感染な ど，重症化することが多いので注意を要する。

また，麻疹，水痘，带状疮疹，風疹などのウイ ルス感染む，小児科なとでは悩まされることが多 い.

HBs抗原と肝炎との関連が, 種々の角度から研 
究されている.母児感染も知られている。

HBs抗原陽性患者に接触する勤務者一医師，齿 科医師，看護婦，衛生師，また検査材料に接する 臨床検查技師などは，一般的にその感染頻度も高 いことからす注目されている。

感染防止，消毒法，定期検診など，実施すべき 抜本的な問題が少なくない。

（5） その他

終末感染など，剖検例を，臨床経過と対比しつ つ, 微生物の面から考察してみると，弱毒菌や， 真菌，ウイルスなどによる内因感染あるいは外因 感染と思われるものがきわめて多い点，今後の大 きな課題である。

さらに，最近，敗血症の増加がわたくしたちの 細菌検查の結果からむ，注目され，また，尿路 中，気道の慢性感染症などに打いて，七ラチア， 緑膿菌, クレブシェラ, 大腸菌など, グラム陰性 桿菌の増加，乙かもこれらの多種菌の混合感染の 多いことなど，化学療法や病院感染防止の立場か らむ,さらに，臨床細菌学的な攻究が望まれる。

\section{6. 病院感染の制御}

病院感染の発生は，患者や新生児にとつて，予 期しない感染の負荷により原疾患に重大な影響を 及ぼし，時に死に至ることもある。また医療從事 者にとつて重大な影響をらけることになる。

しかし，病院感染はいつ発生するか予断を許さ ない，従来は，ありらるすのとして等閑にされる 傾向があつたが，きわめて危険なことであり，す べての医療関係者が，病院感染の制御に関心を払 らべきである。

欧米では，病院感染による医療事故が賠償請求 訴訟となつているが，本邦でも，その傾向がある のは当然のことであろら.

この病院感染の問題を真剣に考光，徹底した感 染予防の対策や管理が行なわれるか否かによつ て，その実効があがることは，いらまでむない， 今こそ個々の病院の実情に応し，病院感染の発生 要因の検討と，積極的な対策が確立されるべきで ある。
（1）病院感染予防の組織化 とくに院内感染対策委員会の活動

従来は, 病院感染防止について, 個々の病棟, 訩療科あるいは主治医の判断などで処理されてい た。

しかし，医療が近代化し，複雑化するに従が い, 病院感染の発生が増加する傾向にある点から も，それぞれの病院全体としての，一定の根本方 針にもとづき，一貫した病院感染予防のための管 理体制を組織化する必要があると思う。

岩手医大では, つとに学長の命で, 病院長の下 に「院内感染対策委員会」が設けられ，皘極的な 活動を開始している.

病院感染防止のための, 調查, 研究, 対策执よ び病院長の諮問事項などについて，すすめてい る。

委員会は，診療部門，中検部門，薬局部門，看 護部門，給食部門，事務部門，その他から任命さ れ，互選で委員長，副委員長をえらび，活動して いる.

看護部門から婦長，主任クラスの看護婦が参加 し，積極的に努力している。

委員長には川名があたつている.

なお，特徵的なことは，「院内感染担当婦長」 を招き，病院長の下で，総婦長括上び院内感染対 策委員会と密接な連絡をとり，院内感染防止の看 護の指導や，情報の収集，対策にあたつている。

また，「院内感染予防のためのマニュアル」 を，各委員の協力でま之め，64頁の冊子をつく り,これに従つて実践している.

岩手医大で指定した感染症を，婦長，主治医を 通して一定様式で報告させ，これを総婦長室の附 属病院の病室マップに色分けした，マグネットボ タンで表示し, 現時点における感染症の動態の把 握や対処に便にしている。

その他，衛生管理，教育敬蒙などあらゆる努力 をつくしている.

（2）衛生管理の問題

病院内の污染の現況を細菌学的に検査し，これ 


\section{に対処する。}

感染に対し建物の構造, 空調などに留意するの は言うまでもないが，とくに新生児室やクベー ス, ICU, 手術室, 中材, 調材室などは敩重な配 慮が必要であり, また, 感染患者の監視や隔離の ための問題が，つねにあるので，それに対する具 体策をたて実施している。

水道の蛇口, 流し, 便所, 便器, 貯尿びん, 污 物, 排泄物, 検查材料, 魔埃などの処置. 病院漫 具, オムッなどの隇菌, 消毒, 食養での衛生管理 等々, 病院内の衛生管理や清掃など，実施すべき ことをルチン化する。

な拉，見舞や，外来者には，「面会許可」のパ ッヂを与を，面会者を規制している.

（3）勤務者の感染防止

ことに, 減菌, 消毒の理論と実際について, 正 しい方法の実行がのぞまれるので，それについて の教育をし，また，常用消毒剤については，薬局 ですべて調製配布している、膨大なる検体のあつ まる中央臨床検查部での実験室感染防止はことに 大切である。

医療従事者の感染防止は，言らまでむないが， どこの病院でも，自ら範をたれるべき医師，看護 婦が案外, ルーズにしているのではなかららか.

なお，岩手医大では，感染危険のある職場での 勤務者のHBs抗原の測定や, 妊娠可能の女性の風
疹HI抗体の測定なども実施している。

\section{（4）病院感染防止の研修}

本学内での教育，研修はいらまでもないが，岩 手県看護協会, 岩手県医療局での研修会を実施し たり，また，娊下50の病院の院内感染対策委員を あつめての懇話会などを実施して，病院感染防止 のための勉強会や，情報交換などにつとめ，成果 をあげている。

例えば, opportunistic pathogensについて，消毒 剤, 院内感染防止のマニュアルについて, 盛岡日 赤病院新生児室のハイオクリーン・ルームについ て，難治感染症の治療その他などである。

（5）化学療法との関連

大学で使用される化学療法昘の内容とその量な どと, 分離される細菌の薬剤感受性などの関連は 重要な問題である.

また，消毒剤の効果についても同様である：

\section{7. 結 語}

病院感染は，現代医療にとつて等閑にできない 重要な課題である。

これに対処し，その発生要因をさぐり，これに 対する制御をすすめることは，医療にたずさわる すべての人の責務であると考える.

医療関係者を中心とする熱意と努力によつて， 病院感染をなくそうとい5目標に向つて全力をつ くしたいものである. 